\title{
PENGARUH KOMPETENSI, KETERLIBATAN KERJA GURU DAN KOMPENSASI TERHADAP KINERJA GURU SEKOLAH MENENGAH KEJURUAN NEGERI BATAM KEPULAUAN RIAU
}

\author{
denny asmarazisa \\ Prodi Manajemen, Fakultas Ekonomi, Universitas Riau kepulauan \\ apykebenk@yahoo.com
}

\begin{abstract}
Effect of Competence, Work Involvement and Employment Compensation on teachers on teacher performance at Batam State Vocational High School. This study aims to determine the effect of teacher work competency and work involvement and compensation for the performance of Batam State Secondary School Teachers. Sources of data found are primary data obtained directly from the answers from the questionnaire concerned with the research with the above qualifications. Coupled with several references from the researchers themselves. Based on this study, the Competence of Teacher Involvement and Compensation on the Performance of Teachers of Batam State Vocational Middle School Teachers has a significant effect both partially and simultaneously at a 100\% confidence level. The value of $R$ Square in this study is 0.644 which means that only $64.4 \%$ changes in employee performance levels can be explained by Competency, Teacher Involvement, Teacher Performance and Teacher Compensation at Batam Vocational High School while the rest are influenced by other variables that are not observed. in this research.
\end{abstract}

Keywords: Competence, Employee Engagement, Compensation, and Employee Performance 


\begin{abstract}
Pengaruh Kompetensi, Keterlibatan Kerja dan Kompensasi Ketenaga kerjaan guru terhadap Kinerja guru di sekolah menengah kejuruan Negeri Batam. Penelitian ini bertujuan untuk mengetahui pengaruh Kompetensi Kerja guru dan Keterlibatan kerja dan Kompensasi terhadap Kinerja Guru Sekolah Menengah Negeri Batam. Sumber data yang ditemukan adalah data primer yang diperoleh langsung dari jawaban dari kuesioner yang bersangkutan dengan penelitian dengan kualifikasi di atas. Ditambah dengan beberapa referensi dari peneliti sendiri. Berdasarkan penelitian ini, Kompetensi Keterlibatan dan Kompensasi Guru terhadap Kinerja Guru Sekolah Menegah Kejuruan Negeri Batam berpengaruh signifikan baik secara parsial, maupun simultan pada tingkat kepercayaan $100 \%$. Nilai $R$ Square pada penelitian ini adalah 0,644 yang berarti hanya 64,4\% perubahan tingkat kinerja karyawan dapat dijelaskan oleh variabel Kompetensi, Keterlibatan Tenaga Pengajar, Kinerja guru dan Kompensasi Guru di Sekolah Menengah Kejuruan Negeri Batam sedangkan sisanya dipengaruhi oleh variabel lain yang tidak diamati. dalam penelitian ini.
\end{abstract}

Kata kunci: Kompetensi, Keterlibatan Karyawan, Kompensasi, dan Kinerja Karyawan

Pengaruh 


\section{A. PENDAHULUAN}

Tenaga Kerja merupakan salah satu aset yang sangat penting. Manusia yang merupakan tenaga Guru bagi sekolah kadang kala sering diabaikan sebagai aset yang tak berharga. Tak jarang, Pemerintah hanya mengganggap bahwa tenaga Kependidikan (Guru) sebagai beban yang harus selalu ditekan untuk mengurangi biaya dalam Mengajar. Namun, itu merupakan pandangan yang kurang tepat.

Kinerja Guru adalah keterlibatan mengajar. Keterlibatan Mengajar merupakan tingkatan keikutsertaan aktif individu dalam Mengajar dan sejauh mana individu menganggap mengajar itu sebagai hal penting,yang mempengaruhi harga dirinya. Chughtai (2010) Karyawan yang mempunyai tingkat keterlibatan pekerjaan yang tinggi,sangat memihak perusahaanya dan benar-benar peduli dengan bidang pekerjaan yang dilakukan olehnya. Karyawan yang terlibat dalam perkerjaan, cenderung lebih termotivasi untuk bekerja dengan baik.

Keterlibatan Guru telah menjadi keharusan strategis,tetapi Pemerintah tidak menyadari pentingnya memberi kesempatan kepada seorang tenaga pengajar dalam pengambilan keputusan, berpatisipasi aktif dalam pekerjaan, mempersepsikan situasi mengajar sebagai hal yang penting sehingga hal ini perlu untuk di perhatikan, Guru merasa di hargai di tempat kerja. Kurangnya Pemerintah dalam memberi kesempatan kepada Tenaga pengajar untuk terlibat,dapat memotivasi kerja yang rendah, Faslah (2010). Karyawan yang tidak mendapatkan kesempatan tersebut tidak memiliki kebutuhan untuk bertanggung jawab, berprestasi, mendapatkan pengakuan dan peningkatan harga diri. Stabilitas adalah alasan utama mengapa keterlibatan karyawan dibutuhkan organisasi dalam menghadapi era globalisasi, Agung Adi (2012).

Kompetensi merupakan yang berhubungan dengan memimpin oganisasi dan orang untuk mencapai maksud, visi, dan tujuan organisasi. Kompetensi berkenaan dengan leadership meliputi kepemimpinan visioner, berpikir strategis, membangun komitmen organisasional

Kompensasi sangatlah penting bagi Tenaga Pengajar karena besarnya apabila kompensasi diberikan secara tepat dan benar maka karyawan akan merasa puas dan termotivasi untuk lebih giat lagi bekerja. Kompensasi yang di terima seorang pengajar mencerminkan status, pengakuan dan tingkat pemenihan kebutuhan yang di nikmati oleh guru. Sekolah sebagai wadah berharap agar kompensasi yang diberikan dapat meningkatkan kinerja tenaga pengajar. Pemberian kompensasi meliputi pemberian gaji dan upah, dan pemberian tunjangan lainnya. 


\section{Rumusan Masalah}

Berdasarkan uraian dalam latar belakang diatas maka rumusan masalah dalam penelitian ini adalah :

1. Apakah

Kompetensi berpengaruh terhadap kinerja Tenaga Pengajar di Sekolah Menegah Kejuruan Batam?

2. Apakah keterlibatan kerja Guru berpengaruh terhadap kinerja Pengajar Di SMK Negeri Batam ?

3. Apakah kompensasi berpengaruh terhadap kinerja Pengajar Di SMK Negeri Batam ?

4. Apakah pengaruh antara Kompetensi, Keterlibatan Kerja guru dan Kompensasi secara bersama -sama terhadap kinerja Guru ?

\section{Tujuan Penelitian}

Berdasarkan latar belakang dan rumusan masalah yang ada, maka penelitian ini dilakukan dengan tujuan :

1. Untuk mengetahui sejauh mana pengaruh Kompetensi terhadap kinerja Guru SMK Negeri Batam .

2. Untuk mengetahui sejauh mana pengaruh keterlibatan kerja Guru terhadap kinerja kerja pengajar SMK Negeri Batam .

3. Untuk mengetahui sejauh mana pengaruh kompensasi terhadap kinerja kerja Tenaga Pengajar SMK Negeri Batam .

4. Untuk mengetahui sejauh mana pengaruh antara kompetensi, keterlibatan kerja Tenaga Pengajar dan kompensasi terhdap kinerja kerja guru SMK Negeri Batam .

\section{B. TINJAUAN PUSTAKA}

a) Pengertian Kompetensi

Kompetensi mencakup berbagai faktor teknis dan non teknis,kepribadian dan tingkah laku,soft skill dan hard skill,kemudian banyak dipergunakan sebagai aspek yang dinilai banyak perusahaan untuk merekrut karyawan ke dalam organisasi. Sedarmayanti (2016) kompetensi adalah karakteristik mendasar yang dimiliki seseorang yang berpengaruh langsung terhadap atau dapat memprediksikan kinerja yang sangat baik dengan kata lain kompetensi adalah apa yang outstanding performers lakukan lebih sering,pada lebih banyak situasi,dengan hasil yang lebih baik,daripada apa yang dilakukan penilaian kebijakan

Noor Fuad mendefinisikan kompetensi 
sebagai kombinasi dari keterampilan (skill), pengetahuan (knowledge), dan perilaku (attitude). Keterampilan, pengetahuan, dan perilaku itu dapat diamati dan diterapkan secara kritis untuk suksesnya sebuah organisasi dan prestasi kerja serta kontribusi pribadi pegawai terhadap organisasinya.

Sedarmayanti (2016) Terdapat enam karakteristik kompetensi, yaitu sebagai berikut :

1. Motif adalah pemikiran/niat dasar konstan yang mendorong individu bertindak/berprilaku. Contoh : ingin dihargai,dorongan mempengaruhi orang lain.

2. Sifat/ciri adalah karakteristik yang relative konstan pada tingkah laku seorang.

Contoh : seorang pendengar yang baik.

3. Citra diri adalah presepsi individu terhadap dirinya.

Contoh : menjadi seorang pengikut atau seorang oposan.

4. Pengetahuan adalah informasi yang dimiliki/dikuasai seseorang dalam bidang tertentu.

Contoh : mengerti ilmu manajemen keuangan.

5. Keterampilan adalah keahlian/kecakapan melakukan sesuatu dengan baik.
Contoh : kemampuan

mengemudi

6. Peran sosial adalah citra yang diproyeksikan seseorang kepada orang lain.

Contoh : melihat / mempromosikan dirinya sebagai pemimpin.

\section{b) Kompetensi}

\section{a. Kategori Kompetensi}

Wibiwo (2015) memberikan lima kategori kompetensi yang terdiri dari :

1. Task Achievement merupakan kategori kompetensi yang berhubungan dengan kinerja baik. Kompetensi yang berkaitan dengan task achievement ditunjukkan oleh orientasi pada hasil, mengelola kinerja, memengaruhi, inisiatif, inovasi dan keahlian teknis.

2. Relationship merupakan kategori kompetensi yang berhubungan dengan komunikasi dan bekerja baik dengan orang lain dan memuaskan kebutuhannya. Kompetensi yang berhubungan dengan relationship meliputi kerjasama, orientasi pada pelayanan, kepeduliaan antar pribadi, penyelesaian konflik. 
3. Personal

Attribute

merupakan kompetensi

instrinsik individu dan menghubungkan bagaimana orang berpikir, merasa, belajar, dan berkembang. Personal attribute merupakan kompetensi yang meliputi : integritas dan kejujuran, pengembangan diri, ketegasan, kualitas keputusan, berpikir analitis, dan berpikir konseptual.

4. Managerial merupakan kompetensi yang secara spesifik berkaitan dengan pengelolaan, pengawasan, dan mengembangkan orang lain. Kompetensi manajerial berupa : memotivasi, memberdayakan, dan mengembangkan orang lain.

Leadership merupakan kompetensi yang berhubungan dengan memimpin oganisasi dan orang untuk mencapai maksud, visi, dan tujuan organisasi. Kompetensi berkenaan dengan leadership meliputi kepemimpinan visioner, berpikir strategis, membangun komitmen organisasional

Wibowo (2015) mengatakan strata kompetensi dapat dipilah-pilah menurut stratanya dapat dibagi menjadi core competencies, managerial competencies, dan functional competencies.

1. Core competencies merupakan kompetensi inti yang dihubungkan dengan strategi organisasi sehingga harus dimiliki oleh semua karyawan dalam organisasi.

2. Managerial Competencies merupakan kompetensi yang mencerminkan aktivitas manajerial dan kinerja yang diperlukan dalam peran tertentu.

\section{Functional}

Competencies merupakan kompetensi yang menjelaskan tentang kemampuan peran tertentu yang diperlukan dan biasanya dihubungkan dengan keterampilan profesional

\section{b. Tipe Kompetensi}

Menurut Moeheriono (2009) mengatakan tipe kompetensi dapat dibagi menjadi dua tipe kompetensi yaitu sebagai berikut :

\section{Kompetensi Individu}

Dalam kompetensi individu ini dapat dikategorikan atau dikelompokkan menjadi dua, terdiri atas:

a. Threshold Competence atau dapat disebut kompetensi minimum, yaitu kompetensi dasar yang harus dimiliki oleh seseorang, misalnya kemampuan pengetahuan atau keahlian dasar seperti kemampuan mambaca dan menulis. Contohnya jika seseorang menjadi manajer keuangan, minimal harus mempunyai pengetahuan dan 
keahlian khusus akuntansi atau keuangan.

b. Differentiating Competence yaitu kompetensi yang membedakan seseorang berkinerja tinggi atau berkinerja rendah dengan karyawan lainnya, misalnya seseorang yang yang memiliki orientasi motivasi tinggi biasanya yang diperhatikan adalah pada tujuan melebihi apa yang ditargetkan oleh organisasi dalam standar kerja. Akan tetapi, justru kompetensi dari pengetahuan dan keterampilan atau keahlian labih mudah untuk dikembangkan apabila akan menambah atau meningkatkan kompetensi tersebut yaitu dengan cara menambah program pendidikan dan pelatihan bagi pegawai yang masih dianggap kurang kompetensinya.

Secara rinci, ada lima dimensi kompetensi yang harus dimiliki oleh semua individu, yaitu sebagai berikut :

1. Task skills yaitu keterampilan untuk melaksanakan tugastugas rutin sesuai dengan standar di tempat kerja.

2. Task management skills yaitu keterampilan untuk mengelola serangkaian tugas yang berbeda yang muncul dalam pekerjaan.

3. Contingency management skill yaitu keterampilan mengambil tindakan yang cepat dan tepat bila timbul suatu masalah dalam pekerjaan.

4. Job role environment skill yaitu keterampilan untuk bekerjasama serta memelihara kenyamanan lingkungan kerja.

5. Transfer skill yaitu keterampilan untuk beradaptasi dengan lingkungan kerja baru.

2. Kompetensi Jabatan

Moeheriono (2009) Seseorang agar mendapat kinerja tinggi secara maksimal seharusnya kompetensi individu yang dimiliki harus sesuai atau cocok dengan kompetensi jabatan yang diembannya, hal ini akan mengakibatkan terjadi kecocokan dengan kemampuan yang dimilikinya. Berdasarkan standar kompetensi pada kompetensi jabatan, tercakup dua komponen yang mendasar, yaitu kompetensi utama dan kompetensi pendukung yang rinciannya adalah sebagai berikut :

1. Kompetensi Utama merupakan kompetensi yang harus dimiliki seseorang berkaitan dengan suatu jabatan atau tugas pekerjaan pada lingkup tertentu. Seperti : Akuntabilitas, organisasi 
pembelajar, dan menentukan masalah dan memecahkannya.

2. Kompetensi Pendukung adalah kompetensi yang diperlukan untuk membantu atau mendukung terwujudnya pelaksanaan jabatan tertentu, yang terdiri atas berikut : komunikasi, dan teknologi informasi.

\section{c. Keterlibatan Kerja}

Robbins \& Judge (2010) mendefinisikan keterlibatan kerja adalah suatu ukuran sampai dimana individu secara psikologis memihak pekerjaan mereka dan menganggap penting tingkat kinerja yang dicapai sebagai penghargaan diri. Sedangkan menurut Veithzal dan Mulyadi (2012) keterlibatan kerja merupakan derajat sejauh mana seseorang memihak secara psikologis terhadap pekerjaannya dan menganggap tingkat kinerjanya penting untuk harga diri. Semua karyawan yang ada dalam suatu perusahaan harus terlibat dalam pekerjaanya masing-masing dan memiliki rasa kepedulian terhadap pekerjaannya demi mencapai tujuan perusahaan.

Shuck dan Wollard (2010) dalam Shuck, et al. (2011), mengemukan bahawa keterlibatan kerja mempunyai pengaruh kognitif individu secara emosional dan perilaku yang diarahkan menuju hasil yang diinginkan oleh organisasi. Keterlibatan karyawan adalah suatu proses untuk mengikutsertakan para karyawan pada semua level organisasi dalam pembuatan keputusan dan pemecahan masalah. Terdapat manfaat keterlibatan karyawan yaitu:

1. meningkatkan kemungkinan dihasil-kannya keputusan yang baik, rencana yang lebih baik, atau perbaikan lebih efektif karena juga mencakup pandangan dan pemikiran dari pihak pihak yang berhu-bungan langsung dengan situasi kerja.

2. Keterlibatan karyawan juga meningkatkan rasa memilki dan tanggung jawab atas keputusan dengan melibatkan orang orang yang harus melaksanaka (Fandy Tjiptono \& Anastasia Diana, 2003).

Menurut Borwn (2009) karyawan dapat mengidentifikasikan diri secara psikologis dengan menganggap pekerjaannya penting untuk dirinya selain untuk organisasi. Sedangkan menurut Khaerul Umam (2010) keterlibatan kerja dapat didefinisikan sebagai derajat seseorang secara psikologis mengartikan dirinya dengan pekerjaan dan menganggap tingkat kinerjanya sebagai hal penting bagi harga diri.

Kesimpulan dari beberapa teori diatas maka keterlibatan kerja dapat didefinisikan sebagai tingkatan individu berpartisipasi aktif di dalamnya, menginvestigasikan waktu dan energi untuk pekerjaannya dan 
menganggap pekerjaan penting sebagai keseluruhan kesan diri.

\section{c. Kompensasi}

Kompensasi adalah segala sesuatu yang diterima karyawan sebagai balas jasa untuk mereka (Handoko dalam Yulharsari, 2012). Sedangkan Stone dalam Suwatno dan Priansa (2011) kompensasi adalah setiap bentuk pembayaran yang diberikan kepada karyawan sebagai pertukaran pekerjaan yang mereka berikan kepada majikan.

Flippo dalam Suwatno dan Priansa (2011) kompensasi merupakan pemberian imbalan jasa yang layak dan adil kepada karyawan-karyawan karena mereka telah memberi sumbangan kepada pencapaian organisasi. Hal ini sama dengan apa yang dikatakan oleh Bangun (2012) bahwa kompensasi adalah imbalan yang dibayarkan kepada karyawan atas jasa yang mereka sumbangkan pada pekerjaannya.

Menurut Marwansyah (2010) kompensasi merupakan imbalan secara langsung, imbalan tidak langsung dalam bentuk manfaat tambahan (benefit) dan bentuk pemberian layanan tambahan serta insentif yang ditujukan untuk memotivasi pekerja agar mencapai produktivitas yang lebih tinggi. Konsep mengenai kompensasi juga dikembangkan oleh Gomez-Mejia et al (2012) yang menyatakan bahwa kompensasi merupakan bentuk penghargaan dari perusahaan kepada karyawan karena kontribusi mereka. Selanjutnya, Gomez-Mejia membagi kompensasi ke dalam tiga komponen; kompensasi dasar, insentif, dan benefit (kompensasi tidak langsung). Sebagai dasar perancangan kuesioner, penulis menggunakan tiga komponen kompensasi yang disebutkan oleh Gome-Mejia (2012) yaitu kompensasi dasar, insentif, dan benefit.

\section{Kompensasi menurut} Wayne dalam Dhermawan (2012) meliputi bentuk tunai langsung, pembayaran tidak langsung dalam bentuk manfaat karyawan, dan insentif untuk memotivasi karyawan agar bekerja keras untuk mencapai produktivitas yang tinggi.

\section{e. Kinerja}

Kinerja adalah sebauah tampilan keadaan saecara utuh atas perusahaan selama periode tertentu, merupakan hasil atau prestasi yang dipengaruhi pleh kegiatan operasional perusahaan dalam memanfaatkan sumber-sumber daya yang di milki menurut Helfert dalam Veithzal (2010), Istilah kinerja digunakan untuk menguur hasil yang telah di capai sehubung dengan kegiatan atau aktifitas perusahaan, apakah kinerja perusahaan telah baik atau perlu adanya evaluasi-evaluasi kebelakang mengenai hasil yang dicapai.kenerja adalah hasil pekrjaan yang dicapai seeseorang atau kelomok sperti standar hasil kerja, target yang ditentukan selama periode tertentu yang berpedoman pada norma,standar operasional prosedur,kriteria dan fungsi yang telah ditetapkan atau yang 
berlaku dalam perusahaan Bangun,2012).

Beberapa penilaian kinerja menurut para ahli yaitu kinerja adalah apa yang dicapai atau prestasi kerja yang di lihat. Selain itu kinerja dalah gambaran mengenai tingkat pencapaian pelaksanaan suatu kegiatan / program / kebijakan dan mewujudkan sasaran, tutjuan, misi dan visi organisasi yang tertuang dalam perumusan skema strategis (strategic planning ) suatu organisasi. Pendapat lainnya menyatakan bahwa kinerja adalah hasil kerja yang dapat dicapai oleh seseorang atau kelompok orang dalam organisasi, sesuai dengan wewenang dan tanggung jawab masing-masing dalam rangka upaya mencapai tujuan organisasi bersangkutan secara legal dan tidak melanggar hokum sesuai denggan moral dan etika. Dengan demikian kinerja seseorang juga menentukan kinerja organisasi yang harus berpedoman kepada aturan-aturan yang berlaku secara umum ( yang di keluarkan oleh pemerintah, organisasi profesi dan organisasi lainnya ).

\section{Kerangka Pemikiran}

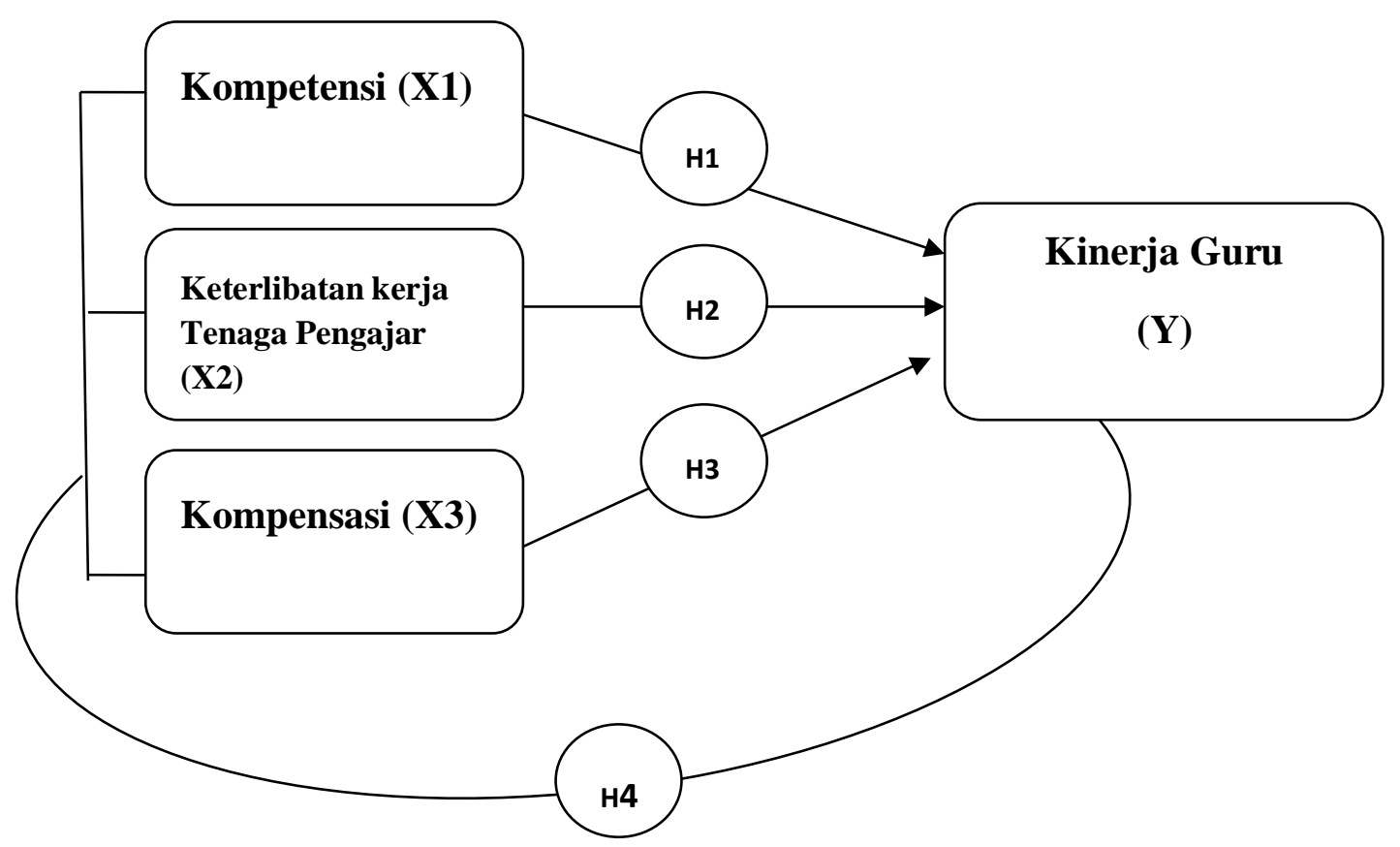

\section{Hipotesis Penelitian}

1. H1 : Diduga mempunyai pengaruh yang signifikan antara kompetensi (X1) terhadap kinerja Guru (Y).
2. H2 : Diduga mempunyai pengaruh yang signifikan antara keterlibatan kerja Tenaga Pengajar (X2) terhadap kinerja Guru (Y).

3. H3 : Diduga mempunyai pengaruh yang signifikan antara 
kompensasi (X3) terhadap kinerja Guru $(\mathrm{Y})$.

4. H4 : Diduga mempunyai pengaruh yang signifikan antara kompetensi (X1), keterlibatan kerja Guru (X2) dan kompensasi (X3) secara bersama-sama terhadap kinerja Guru(Y).

\section{METODE PENELITIAN}

Teknik Analisis Data menurut Sugiyono (2006: 169 ) Mengemukakan teknik analisis data sebagai berikut: mengelompokan data berdasarkan variabel dan seluruh responden, menyajikan data tiap variabel yang di teliti, melakukan perhitungan untuk mengaji hipotesis yang telah di ajukan.

Berdasarkan pengertian di atas dapat di simpulkan bahwa analisis data merupakan kegiatan setelah data dan seluruh responden terkumpul, kemudian data tersebut di kelompokan berdasarkan variabel dan jenis responden, data di sajikan menurutvariabel yang di teliti, serta melakukan perhitungan untuk menjawab rumusan masalah dan melakukan perhitungan untuk menguji hipotesis yang telah di ajukan. analisia deskriktif dalam penelitian ini mengemukakan tentang data dan responden berupa jenis kelamin, umur, lama bekerja, pendidikan, kedudukan di perusahaan. Dan untuk mengetahui jawaban dari responden maka di baut kuisyoner yang nanti akan di hitung presentasenya. Penelitian ini menggukanan bantuan SPSS versi 16 dengan uji parametrik

Untuk mengetahui pengaruh Kompetensi, Keterlibatan Kerja, Kompensasi Terhadap Kinerja Guru SMK Negeri Batam terdapat kinerja Guru sebanyak 95 orang Tenaga Pengajar yang di jadikan sampel atau responden. Gambaran umum karateristik responden dalam tabel ini berikut ini di uraikan persentase responden tersebut yang mencakup jenis kelamin, usia dan tingkat pendidikan. Data tersebut di olah oleh SPSS.

Uji kualitas data meliputi pebgujuian validitas, reabilitas, uji asumsi klasik meliputi dari uji normalitas, uji multikonearitas, dan uji heteroskedastisitas. Metode analisis regresi berganda dan terdapat pengujian hipotesis (uji $t$ dan uji f) dan koefisiensi determinan $\left(R^{2}\right)$.

\section{HASIL PENELITIAN DAN PEMBAHASAN}

Pada umumnya responden dalam penelitian ini sebagian besar berjenis kelamin laki - laki yang berusia 20 30 tahun. Responden di domisili kalangan pendidikan S1 Pendidikan Ditambah S2 Diluar Sarjana Pendidikan .

Syarat minimum suatu isntrumen penelitian ini menggunakan kuisyoner dinyatakan apabila terdapat kolerasi anta butir dan skor total tersebut positif dan nilainya lebih dari 0,50. Hasil dari instrumen reabilitas yang di peroleh variable - 
variable penelitian sebesar 0,777 sehingga bisa dinyatakan reliabel. Hasil uji normalitas berdasarkan normalitas histogram Regression Standardized Residual dan uji Kolmogorov Smirnov dengan hasil $0,984>0,05$ menyatakan bahwa data terdistribusi normal. Hasil uji multikolinearitas menunjukan nilai tolerance untuk Kompetensi, Keterlibatan kerja karyawan, dan Kompensasi. kompetensi memilki tolerance $0,522>0,10$ dan VIF sebesar $1,915<10$, variable keterlibatan kerja karyawan memiliki tolerance $0,682>0,10$ dan $\mathrm{VIF}$ sebesar 1,467 variable kompensasi memiliki tolerance sebesar $0,538>$ 0,10 dan VIF sebesar 1,857 dan dapat disimpulkan nilai tersebut sehingga dapat di nyatakan multikolinieritas.

Hasil uji heteroskedastisitas berdasarkan Scatter plot of Regression Standaridized Residual dapat di ketahui bahwa titik titik menyebar merata dengandi sekitar sumbu 0 dan Y.

Tabel 4.14 Hasil Uji Parsial (T-test)

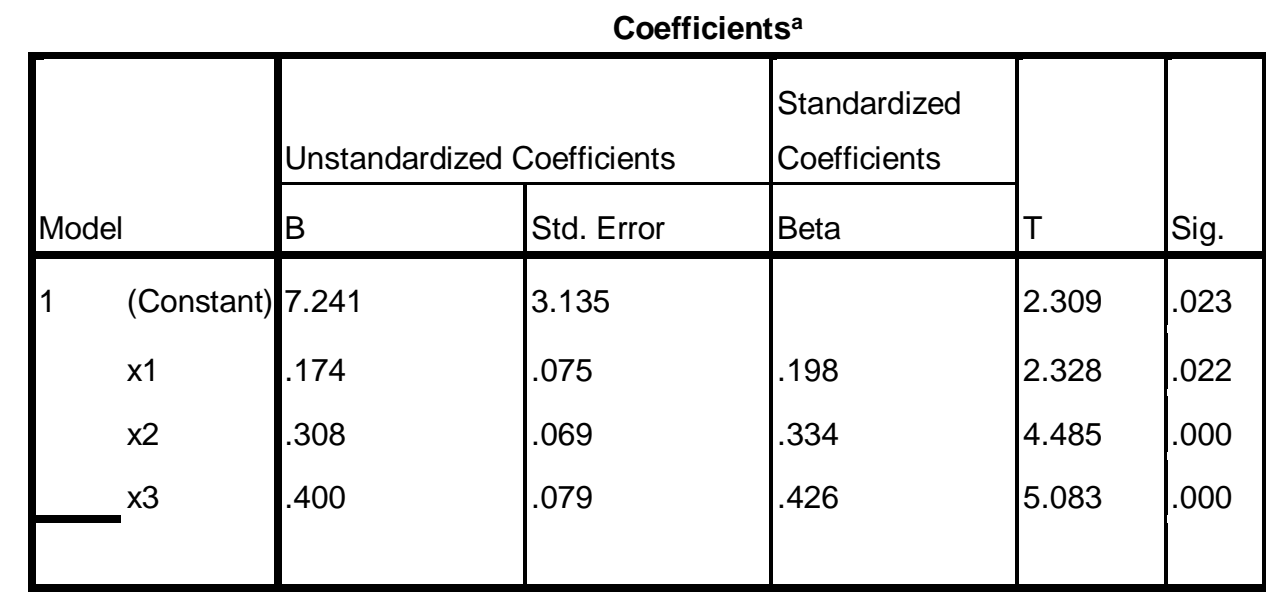

\section{Kompetensi}

Berdasarkan pada tabel diatas, maka dapat diketahui bahwa hasil uji parsial dapat dilihat dikolom Sig, nilai probabilitas signifikan $(\alpha)$. Pada masing-masing variabel independen menunjukkan nilai yang lebih kecil dari probabilitas signifikan $(\alpha)=0,05$. Hasil uji parsial pada variable Kompetensi menunjukkan nilai sebesar $0,022<$ 0,05 dan $\mathrm{t}_{\text {hitung }} 2,328$ sebesar $>\mathrm{t}$ tabel sebesar 1,661.

\section{Keterlibatan Kerja Tenaga Pengajar.}

Berdasarkan pada tabel diatas, maka dapat diketahui bahwa hasil uji parsial dapat dilihat dikolom Sig,

nilai probabilitas signifikan $(\alpha)$. Pada masing-masing variabel

independen menunjukkan nilai yang lebih kecil dari probabilitas signifikan $(\alpha)=0,05$. Hasil uji parsial pada variable Keterlibatan Kerja Pengajar menunjukkan nilai 
sebesar $0,000<0,05$ dan $\mathrm{t}$ hitung 4,485

sebesar $>\mathrm{t}$ tabel sebesar 1,661.

\section{Kompensasi}

Berdasarkan pada tabel diatas, maka dapat diketahui bahwa hasil uji parsial dapat dilihat dikolom Sig, nilai probabilitas signifikan $(\alpha)$.
Pada masing-masing variabel independen menunjukkan nilai yang lebih kecil dari probabilitas signifikan $(\alpha)=0,05$. Hasil uji parsial pada variable Kompensasi menunjukkan nilai sebesar $0,000<$ 0,05 dan $\mathrm{t}$ hitung 5,083 sebesar $>\mathrm{t}$ tabel sebesar 1,661.

\section{Tabel 4.15 Uji F}

\begin{tabular}{|ll|l|l|l|l|l|}
\hline \multicolumn{2}{|c|}{ ANOVA $^{\text {b }}$} & \\
\hline 1 & Sum of Squares & Df & Mean Square & F & Sig. \\
\hline & \begin{tabular}{ll|l|l|l} 
Regression \\
Residual
\end{tabular} & 1195.505 & 3 & 398.502 & 57.703 & $.000^{\mathrm{a}}$ \\
& 628.453 & 91 & 6.906 & & \\
Total & 1823.958 & 94 & & & \\
\hline
\end{tabular}

Dari tabel diatas di ketahui nilai $\mathrm{F}$ hitung sebesar 57,703 sedangkan $\mathrm{F}$ tabel 2,70 karena nilai $F_{\text {hitung }}>F_{\text {table }}$ maka Ho ditolak dengan demikian model regresi antara kompetensi, keterlibatan kerja Pengajar dan kompensasi terhadap kinerja guru adalah berbentuk linear.

Hasil uji $\mathrm{F}$ dapat dilihat pada tabel dikaitkan dengan hipotesis yang diajukan yaitu :

1. $\mathrm{H}_{\mathrm{o}}$ : tidak terdapat pengaruh yang positif dan signifikan dari variable kompetensi, keterlibatan kerja Pengajar dan kompensasi terhadap kinerja guru SMK Negeri Batam .

2. $\mathrm{H}_{\mathrm{a}}$ : terdapat pengaruh yang positif dan signifikan dari variable kompetensi, keterlibatan kerja Pengajar dan kompensasi terhadap kinerja Guru SMK Negeri Batam

Hasil perhitungan statistic menunjukan nilai $\mathrm{f}$ hitung $=57,703>$ 2,70 (f tabel) dengan signifikan sebesar $0,000<0,05$. Yang berarti $\mathrm{H}_{\mathrm{a}}$ diterima dan $\mathrm{H}_{\mathrm{o}}$ ditolak. Hal ini berarti bahwa secara bersama - sama kompetensi, keterlibatn kerja karyawan dan kompensasi mempunyai pengaruh yang positif dan signifikan terhadap kinerja Guru SMK Negeri Batam 


\section{E. PEMBAHASAN}

Tabel 4.16 Hasil Uji Koefisiensi Determinasi $\left(\mathbf{R}^{\mathbf{2}}\right)$

\begin{tabular}{|l|l|l|l|l|}
\multicolumn{5}{|c|}{ Model Summary } \\
Model & $\mathrm{R}$ & $\mathrm{R}$ Square & $\begin{array}{l}\text { Adjusted R } \\
\text { Square }\end{array}$ & $\begin{array}{l}\text { Std. Error of } \\
\text { the Estimate }\end{array}$ \\
\hline 1 & $.810^{\mathrm{a}}$ & .655 & .644 & 2.62794 \\
\hline
\end{tabular}

Hasil perhitungan dapat diketahui bahwa koefisien determinasi ( adjusted R2) yang di peroleh sebesar 0,644 dan termasuk dalam kategori tepat, menunjukkan bahwa kontribusi variasi nilai $\mathrm{x} 1, \mathrm{x} 2, \mathrm{x} 3$ dalam mempengaruhi variasi nilai Y adalah sebesar $64,4 \%$ sisanya $35,6 \%$ merupakan konstribusi variabel lain yang tidak di ikut sertakan di model penelitian ini.

\section{Terdapat Pengaruh Kompetensi Terhadap Kinerja Guru}

Berdasarkan analisis data dan pengujian hipotesis di atas di peroleh bahwa nilai $\mathrm{t}$ hitung $>\mathrm{t}$ tabel $(2,328>$ $1,661)$ dan signifikan $<0,05(0,022$ $<0,05)$ maka hipotesis 1 di terima, jika dapa di simpulkan bahwa kompensasi (X1) secara parsial berpengaruh signifikan terhadap kinerja Guru ( $\mathrm{Y}$ ). Berdasarkan kriteria di atas variabel Kompetensi memiliki peran penting dalam mempengaruhi kinerja Guru SMK Negeri Batam.

\section{Terdapat Pengaruh Keterlibatan} Kerja Pengajar Terhdap Kinerja Guru.

Berdasarkan analisis data dan pengujian hipotesis di atas di peroleh bahwanilai $\mathrm{t}$ hitung $>\mathrm{t}$ tabel $(4,485>$ $1,661)$ dan signifikan $<0,05(0,000$ $<0,05$ ) maka hipotesis 1 di terima, jika dapat di simpulkan bahwa kompensasi (X2) secara parsial berpengaruh signifikan terhadap kinerja Guru (Y). Berdasarkan kriteria di atas variabel Keterlibatan Kerja Pengajar memiliki peran penting dalam mempengaruhi kinerja guru SMK Negeri Batam .

\section{Terdapat Pengaruh Kompensasi Terhadap Kinerja Guru}

Berdasarkan analisis data dan pengujian hipotesis di atas di peroleh bahwa nilai $\mathrm{t}$ hitung $>\mathrm{t}$ tabel $(5,083>$ $1,661)$ dan signifikan $<0,05(0,000$ $<0,05$ ) maka hipotesis 1 di terima, jika dapa di simpulkan bahwa kompensasi ( X3 ) secara parsial berpengaruh signifikan terhadap kinerja guru ( $\mathrm{Y}$ ). Berdasarkan kriteria di atas variabel Keterlibatan Kerja Pengajar memiliki peran 
penting dalam mempengaruhi kinerja Guru Batam .

\section{Terdapat Pengaruh Kompetensi, Keterlibatan Kerja, Kompensasi Terhadap Kinerja Guru}

Dari Hasil uji F memperlihatkan nilai $\mathrm{f}$ hitung $=57,703>2,70(\mathrm{f}$ tabel ) dengan signifikasi sebesar $0,000<0,05$. Yang berarti $\mathrm{Ha}$ diterima dan $\mathrm{HO}$ di tolak, hal ini berarti bahwa secara bersama - sama atau simultan Kompetensi, Keterlibatan Kerja Pengajar, Kompensasi mempunyai pengaruh yang positif dan signifikan terhadap kinerja Guru Batam .

\section{F. KESIMPULAN DAN SARAN}

\section{Kesimpulan}

Berdasarkan hasil analisis dan pembahasan pada bab - bab sebelumnya, dapat di simpulkan :

\section{Terdapat Pengaruh Kompetensi Terhadap Kinerja Guru.}

Bedasarkan analisis data dan pengujian hipotesis di atas di peroleh bahwa nilai $\mathrm{t}$ hitung $>\mathrm{t}$ tabel $(2,328>$ $1,661)$ dan signifikan $<0,05(0,022$ $<0,05$ ) maka hipotesis 1 di terima, jika dapat di simpulkan bahwa kompensasi (X1) secara parsial berpengaruh signifikan terhadap kinerja Guru ( $\mathrm{Y}$ ). Berdasarkan kriteria di atas variabel Kompetensi memiliki peran penting dalam mempengaruhi kinerja Guru SMK Negeri Batam .

\section{Terdapat Pengaruh Keterlibatan Kerja Pengajar Terhadap Kinerja Guru.}

Berdasarkan analisis data dan pengujian hipotesis di atas di peroleh bahwa nilai $\mathrm{t}$ hitung $>\mathrm{t}$ tabel $(4,485>$ $1,661)$ dan signifikan $<0,05(0,000$ $<0,05)$ maka hipotesis 1 di terima, jikadapa di simpulkan bahwa kompensasi (X2) secara parsial berpengaruh signifikan terhadap kinerja Guru ( $\mathrm{Y}$ ). Berdasarkan kriteria di atas variable lKeterlibatan Kerja Pengajar memiliki peran penting dalam mempengaruhi kinerja Guru Batam .

\section{Terdapat Pengaruh Kompensasi Terhadap Kinerja Guru.}

Berdasarkan analisis data dan pengujian hipotesis di atas di peroleh bahwa nilai $\mathrm{t}$ hitung $>\mathrm{t}$ tabel $(5,083>$ 1,661 ) dan signifikan $<0,05(0,00<$ 0,05 ) maka hipotesis 1 di terima, jika dapat di simpulkan bahwa kompensasi ( X3 ) secara parsial berpengaruhsignifikan terhadap kinerja Guru ( $\mathrm{Y}$ ). Berdasarkan kriteria di atasvariabel Keterlibatan Kerja Pengajar memiliki peran penting dalam mempengaruhi kinerja Guru di Batam . 
Terdapat Pengaruh Kompetensi, Keterlibatan Kerja, Kompensasi Terhadap Kinerja Guru.

Dari Hasil uji $\mathrm{F}$ memperlihatkan nilai $\mathrm{f}$ hitung $=57,703>2,70(\mathrm{f}$ tabel ) dengan signifikasisebesar $0,000<0,05$. Yang berarti $\mathrm{Ha}$ diterima dan $\mathrm{HO}$ di tolak, hal ini berarti bahwa secara bersama - sama atau simultan Kompetensi, Keterlibatan Kerja Pengajar, Kompensasi mempunyai pengaruh yang positif dan signifikan terhadap kinerja Guru di Batam .

\section{Saran}

Saran - saran yang dapat di ajukan dalam kesempatan ini yaitu :

1. Para pemimpin unit organisasi maupun pemimpin pusat dalam lingkup Batam Hills Golf Resort hendaknya memperhatikan aspek - aspek prestasi kerja guru, karena akan berdampak kepada kinerja Guru.

2. Para pemimpin di lingkup Sekolah Negeri Batam dalam membuat keputusan untuk peningkatan kinerja setiap unit layanan kepada Guru hendak memperhatikan dan mempertimbangkan aspek - aspek yang di harapkan Tenaga Pengajar yaitu : penerapan kompensasi yang selalu berbasis kinerja Pendidikan.

3. Para pemimpin di lingkup Sekolah Sekolah di Batam hendaknya juga memperhatikan lingkungan kerja guru yang bias membuat tenaga Pengajar menjadi tidak konsentrasi dalam pekerjaanya. 
DAFTAR PUSTAKA

Daly, Hamlan. (2016). Pengaruh Kompetensi, Disiplin Kerja dan rhadap Kinerja Pegawai Badan Pemberdayaan Perempuan dan keluarga berencana daerah Provinsi Sulteng.

Fuadi, Muhammad. (2015). Pengaruh Kompensasi, Lingkungan Kerja dan Keterlibatan kerja terhadap kualitas kehidupan kerja pegawai pada dinas pendidikan provinsi Aceh.

Hasibuan. (2016). Pengaruh Motivasi dan Kompensasi terhadap kinerja karyawan PT. Sinar jaya Abadi Bersama.

Hamzah dan Nina Lamatenggo. (2016), teori kinerja dan pengkurannya.PT Bumi Aksara, Jakarta.
Hadiyatno,Didik. (2016). Pengaruh Kompentensi, Kompensasi dan Kepuasan Kerja Terhadap Kinerja Karyawan pada PT. Ciomas Adisatwa Balikpapan.

Liga Suryadana, Aan Hardiana \& Asep Yahya. ( 2014). Pengaruh kepemimpinan, kompetensi dan kompensasi terhadap kinerja pegawai pada dinas pertanian tanaman pangan provinsi jawa barat.

Mutaqiyathun, A.,\& Chaisunah. (2012). Pengaruh Kompensasi dan Lingkunagn kerja terhadap kepuasan kerja karyawan.

Mangkunegara,A.P. (2016), Manajemen sumber daya manusia perusahaan. Bandung : penerbit PT Remaja Rosdakarya. 
Pramudyo. (2016). Analisis faktorfaktor yang mempengaruhi kinerja dosen negeri diperkerjakan pada kopertis wilayah v Yogyakarta.

Sugiyono. (2016), Metode Penelitian Bisnis. Bandung : penerbit ALFABETA.

Sunyoto. (2017), Penelitian Sumber Daya Manusia : Teori, Kuesioner, Alat Statistik, dan Contoh Riset. Yokyakarta : penerbit CAPS ( Center of Academic Publishing Service).

Sedarmayanti. (2017) Manajemen Sumber Daya Manusia: reformasi Birokrasi dan manajemen pegaawai negeri sipil. PT Refika Aditama, Bandung.

Tanto Wijaya dan Fransiska Andreani. (2012). Pengaruh Motivasi dan Kompensasi
Terhadap Kinerja Karyawan

PT. Sinar Jaya Abadi Bersama. 